Jurnal Ilmu dan Teknologi Kesehatan

Vol 9, No 1, Sept 2021

ISSN: 2338-9095 (Print)

ISSN: 2338-9109 (online)

\title{
Public Perspectives Regarding Covid-19 Pandemic: A Survey of Adults in Jakarta Bogor Depok Tangerang Bekasi Area
}

\author{
Desmawati*, Farahdina Bachtiar \\ Faculty of Health Science Universitas Pembangunan Nasional Veteran Jakarta, Indonesia \\ *Email: desmawati@upnvj.ac.id
}

\author{
Article history \\ Posted, Mar 25 $5^{\text {th }}, 2021$ \\ Reviewed, Jul $9^{\text {th }}, 2021$ \\ Received, Aug $28^{\text {th }}, 2021$
}

\section{ABSTRACT}

The first Covid-19 case was reported on March $2^{\text {nd }}, 2020$, in Indonesia. Then, the graphic trend of infected people has risen sharply, particularly in The Jakarta Greater Area: Jakarta, Bogor, Depok, Tangerang, Bekasi (Jabodetabek), as the epicenter. As a quantitative approach, this study aims to investigate people in Jabodetabek about their perspective on the Covid-19 Pandemic. Two hundred ninety-seven residents participated as respondents in fulfilling a selfdeveloped questionnaire spread through online schema. Descriptive analyses were used to explain the data found. The results showed that $65.85 \%$ of the participants have a positive perspective towards characteristics of the Covid-19, 66.13\% have a positive perspective toward values, belief, and culture in the environment related to the Covid-19, $71.11 \%$ have positive awareness of infectious diseases, and $81.32 \%$ have a positive perspective towards services or policies of the government with local wisdom. In conclusion, the public perspective regarding the Covid-19 pandemic in Indonesia, especially people in the Jabodetabek, is good. However, there were still some participants who did not believe in the Covid-19 Pandemic. Increasing people awareness is needed to control Covid-19 transmission in Indonesia. Therefore, it is recommended to increase health promotion activities (rebuild trust, the precautionary principle, social distancing or physical distancing, washing hands and wearing masks), providing psychosocial support (optimism, quick response, and detection, communication with each other).

Keywords: Covid-19 pandemic; Jabodetabek; perspective

\begin{abstract}
ABSTRAK
Kasus Covid-19 pertama dilaporkan di Indonesia pada tanggal 2 Maret 2020. Sejak saat itu, jumlah kasus harian meningkat pesat, khususnya Jakarta-Bogor-Depok-Tangerang-Bekasi (Jabodetabek) sebagai episentrum. Penelitian kuantitatif ini bertujuan untuk mengetahui perspektif masyarakat tentang pandemi Covid-19 di Jabodetabek. Sejumlah 297 warga Jabodetabek berpartisipasi sebagai responden dalam pengisian kuesioner yang didistribusikan melalui media skema online. Proses analisis deskriptif digunakan untuk menjelaskan data yang ditemukan. Hasil riset menunjukkan bahwa $65,85 \%$ partisipan memiliki pandangan positif
\end{abstract}


terhadap karakteristik Covid-19, 66,13\% memiliki pandangan positif terhadap nilai, kepercayaan dan budaya di lingkungannya terkait Covid-19, 71,11\% memiliki kesadaran positif terhadap penyakit infeksi, dan $81,32 \%$ berpandangan positif terhadap pelayanan atau kebijakan pemerintah yang berwawasan kearifan lokal. Kesimpulannya, perspektif masyarakat tentang pandemi Covid-19 di Indonesia sudah baik, khususnya di wilayah sekitar Jakarta. Namun demikian, masih ada sebagian masyarakat yang tidak percaya dengan Covid-19. Peningkatan kesadaran masyarakat diperlukan dalam rangka pengendalian penularan Covid19 di Indonesia. Oleh karena itu, disarankan untuk meningkatkan kegiatan promosi kesehatan (membangun kembali kepercayaan, prinsip kehati-hatian, menjaga jarak, cuci tangan dan memakai masker), memberikan dukungan psikososial (optimisme, respon cepat, dan deteksi, komunikasi satu sama lain).

Kata Kunci: pandemi Covid-19; Jabodetabek; perspektif

\section{INTRODUCTION}

Since the World Health Organization (WHO) declared the novel coronavirus (Covid-19) outbreak as a pandemic (Cucinotta and Vanelli, 2020), the global spread of the virus has occurred rapidly and has raised concerns and questions. Since on March $2^{\text {nd }}, 2020$, Indonesia has reported two confirmed cases of Covid-19. The number of Covid-19 cases on September $1^{\text {st }}, 2020$ increased by 2,755 , bringing the total to 177,571 confirmed cases. The five provinces with the highest cases are DKI Jakarta, West Java, South Sulawesi, East Java, Banten, and Central Java (Kementerian Kesehatan RI, 2020). The increase in the number of cases took place quite rapidly and there has been a spread among provinces in Indonesia, including in Jakarta Metropolitan Area, also known as Jabodetabek (Jakarta - Bogor - Depok Tangerang - Bekasi). The case fatality rate
(CFR) of Covid-19 in Indonesia is around $8 \%$. This is in the spotlight because it is among the highest in the world, even the highest among ASEAN countries (Khaedir, 2020). It may be due to the virulence of SARS-CoV2, the immune factor of the Indonesian people, the lack of availability of health facilities and health workers, lack of effective communication, and lack of knowledge about Covid-19. Thus, efforts are needed to discover the community's perspective related to Covid-19 to avoid being indifferent.

Perspective is a viewpoint, assumption, set of values, and ideas that influence a person's viewing of a phenomenon in a particular situation (Charon, 2010). Therefore in this study, perspective is values that influence one's behaviors in facing a COVID-19 phenomenon. Many studies regarding the Covid-19 Pandemic 
have been published in 2020. However, there are still controversial issues in relation to diagnosis, management, and prevention of Covid-19. Therefore, a study of public perspectives of Covid-19 was conducted in the Jakarta Metropolitan Area and surrounding. This research aims to gain a more in-depth understanding of the attitudes and behaviors of Jabodetabek people on the Covid-19 Pandemic.

\section{METHOD}

This was a quantitative study with a descriptive analysis design. Before the study was conducted, researchers first conducted an ethical review at Health Research Ethics Committee UPNVJ and have passed the ethics review on July $30^{\text {th }}$ 2020, with the number: 2736/VII/2020/KEPK. People living in the Jabodetabek area were recruited to respond to online questionnaires. The data was collected from July to September 2020. As many as 297 people who met inclusion criteria completed online questionnaires. The inclusion criteria included a general public of Jabodetabek area, willing to be a participant, Muslim, aged between 15 and 60 years old, have a smartphone that can be used to access Google form. The Head of the Neighborhood Association, Ketua Rukun Tetangga (RT) assisted to share google form for potential respondents as possible to participate in this research based on the inclusion criteria. All participants signed an online informed consent form. Participant in this study was voluntary and responses remained confidential. Descriptive analyses were used in this study.

\section{RESULTS AND DISCUSSION}

Some tables are provided as follows to illustrate the result of study. Data presented is to explain people perspective related to Covid-19 in focus area as follow: (1) Characteristics of the disease and assumption of people about Covid-19 Pandemic; (2) Values, belief, and culture in the environment; (3) People's awareness of infectious diseases; and (4) Services or policies of the government with local wisdom. However, general information about participant is available in table 1 . 
Desmawati, F. Bachtiar, Public Perspectives Regarding Covid-19 Pandemic: A Survey of 36 Adults in Jakarta Bogor Depok Tangerang Bekasi Area

Table 1. Demographic data of the participants $(n=297)$

\begin{tabular}{|c|c|c|}
\hline Variable & $\mathbf{n}$ & $\%$ \\
\hline Age & \multicolumn{2}{|c|}{ Mean (26.97) } \\
\hline \multicolumn{3}{|l|}{ Gender } \\
\hline Female & 214 & 72.1 \\
\hline Male & 83 & 27.9 \\
\hline \multicolumn{3}{|l|}{ Occupation/Employment } \\
\hline Housewife & 14 & 4.7 \\
\hline Health worker & 17 & 5.7 \\
\hline Private employees & 24 & 8.1 \\
\hline Self employed & 13 & 4.4 \\
\hline Civil servant & 22 & 7.4 \\
\hline Teacher/educator & 37 & 12 \\
\hline Students/college students & 146 & 49.2 \\
\hline Odd jobs & 24 & 8.1 \\
\hline \multicolumn{3}{|l|}{ Never had a plaque before } \\
\hline Never & 234 & 78.8 \\
\hline Eve: SARS & 4 & 1.3 \\
\hline Bird flu & 59 & 19.9 \\
\hline \multicolumn{3}{|l|}{ Are there any Covid-19 patients where you work } \\
\hline Yes & 273 & 91.9 \\
\hline No & 24 & 8.1 \\
\hline \multicolumn{3}{|l|}{ Are there any Covid-19 patients where you live in } \\
\hline Yes & 137 & 46.1 \\
\hline No & 160 & 53.9 \\
\hline \multicolumn{3}{|l|}{ Source of information about Covid-19 } \\
\hline Media television, radio, etc., & 164 & 55.2 \\
\hline Social media; Facebook, Instagram, Twitter & 97 & 32.7 \\
\hline Friend message & 2 & 0.7 \\
\hline Government apparatus; RT, RW & 29 & 9.8 \\
\hline Others, webinar & 5 & 1.7 \\
\hline \multicolumn{3}{|l|}{$\begin{array}{l}\text { Have you ever attend an online webinar to get } \\
\text { accurate information (not a hoax) }\end{array}$} \\
\hline Yes & 142 & 47.8 \\
\hline No & 155 & 52.2 \\
\hline \multicolumn{3}{|l|}{ Do you always get the latest news of Covid-19 } \\
\hline Yes & 267 & 89.9 \\
\hline No & 30 & 10.1 \\
\hline
\end{tabular}


Table 1 shows that most of the participants were women and they were teenagers and young adults of students and college students. Most of the samples received information about Covid-19 from television and radio. Therefore, almost half of the total also attend online seminars to get accurate information. More than $89 \%$ also keep up to uptodate toward Covid-19.

Table 2. Percentage of characteristics of the disease, knowledge, and assumption of people about Covid-19 Pandemic ( $\mathrm{n}=297)$

\begin{tabular}{lcc}
\hline \multicolumn{1}{c}{ Questions } & \multicolumn{2}{c}{ Yes } \\
\cline { 2 - 3 } & $\mathbf{n}$ & \% \\
\hline Do you understand the term Covid-19 & 289 & 97.3 \\
\hline Do you know the way of using personal protective equipment & 257 & 86.5 \\
\hline $\begin{array}{l}\text { Covid-19 is transmitted from wild animals consumption; bats, snakes, etc., to } \\
\text { human being }\end{array}$ & 178 & 59.9 \\
\hline Covid-19 is transmitted from human to human & 291 & 98 \\
\hline Covid-19 di transmitted via droplet when sneezing/cough/burst out laughing & 292 & 98.3 \\
\hline Covid-19 di transmitted by touching equipment; lift, ATM, banister, etc. & 287 & 96.6 \\
\hline Covid-19 di transmitted by touching equipment; change money & 279 & 93.9 \\
\hline Covid-19 di transmitted by shopping items & 282 & 94.9 \\
\hline Covid-19 di transmitted by shake hand & 291 & 98 \\
\hline $\begin{array}{l}\text { Covid-19 more transmitted by people without symptoms than from cases } \\
\text { with symptoms }\end{array}$ & 247 & 83.2 \\
\hline Adults can be infected by Covid-19 & 20 & 6.7 \\
\hline Covid-19 easily attack the elderly with comorbid factors & 290 & 97.6 \\
\hline Have vaccine to prevent Covid-19 & 28 & 9.4 \\
\hline Have specific antiviral to treat Covid-19 & 60 & 20.2 \\
\hline Hib and Pneumokal vaccine can prevent Covid-19 & 96 & 32.3 \\
\hline $\begin{array}{l}\text { The use of blood plasma therapy for recovered patients has been successful } \\
\text { for the treatment of Covid-19 }\end{array}$ & 128 & 43.1 \\
\hline Men are more susceptible to Covid-19 infection than women & 59 & 19.9 \\
\hline Smokers are more susceptible to Covid-19 infection than non-smokers & 206 & 69.4 \\
\hline People from abroad should be avoided & 251 & 84.5 \\
\hline $\begin{array}{l}\text { People who have passed the period of Quarantine (14 days), although } \\
\text { negatives are still avoided }\end{array}$ & 132 & 44.4 \\
\hline $\begin{array}{l}\text { Assume that Covid-19 emerged due to the sophistication of science and } \\
\text { human technology }\end{array}$ & 117 & 39.4 \\
\hline
\end{tabular}

Table 2 shows that the majority of participants in this study have good knowledge on characteristics of the Covid19 Pandemic, including definition, transmission, the use of protective equipment, and more vulnerable group people. Knowledge influences changes in attitude and behaviour (Desmawati et al., 2021). 
Table 3. Percentage of values, belief, and culture in the environment of people related to the Covid-19 Pandemic $(n=297)$

\begin{tabular}{lcc}
\hline \multicolumn{1}{c}{ Questions } & \multicolumn{2}{c}{ Yes } \\
\cline { 2 - 3 } & n & \% \\
\hline Believe that Muslims are immune to Covid-19 because of routine ablution & 247 & 83.2 \\
\hline $\begin{array}{l}\text { Believe that Muslims are immune to Covid-19 because of reading Qur'an } \\
\text { and always remember Allah }\end{array}$ & 202 & 68 \\
\hline $\begin{array}{l}\text { Believe that China Ethnic are more likely to be infected with Covid-19 } \\
\text { because the Covid-19 originated in Wuhan China }\end{array}$ & 92 & 31 \\
\hline $\begin{array}{l}\text { Indonesians who are difficult to be exposed to Covid-19 who like to drink } \\
\text { traditional drinks such as ginger, etc. }\end{array}$ & 158 & 53.2 \\
\hline $\begin{array}{l}\text { Indonesian people have hopes that the spread of Covid-19 in Indonesia will } \\
\text { stop after entering the dry season because the Covid-19 virus dies in hot } \\
\text { weather }\end{array}$ & 143 & 48.1 \\
\hline $\begin{array}{l}\text { Believe that Covid-19 is a test from God } \\
\text { Believe that Covid-19 occurs because humans have damaged the balance of } \\
\text { nature }\end{array}$ & 275 & 92.6 \\
\hline $\begin{array}{l}\text { Believe that Covid-19 arises because humans have tyrannized other } \\
\text { creatures; animal }\end{array}$ & 217 & 73.1 \\
\hline $\begin{array}{l}\text { High population mobility causes Covid-19 to become more massive } \\
\text { The population density in Jabodetabek is the cause of the high spread of } \\
\text { Covid-19 }\end{array}$ & 163 & 54.9 \\
\hline
\end{tabular}

Table 3 shows that most participants believe that the Covid-19 pandemic is related to spiritual and religious aspects. Obedience to religious teachings can increase immunity and prevent contracting Covid-19. The majority of Indonesian people who are Muslim state that the routine of ablution, reading the Qur'an, and always remembering Allah can make the person always clean and have a calm soul so as to avoid the virus (Desmawati, Kongsuwan and Chatchawet, 2019; Desmawati, Kongsuwan and Chatchawet, 2020). In addition, the culture and habits of the Indonesian people to drink traditional ingredients such as ginger and turmeric can also increase immunity because they contain natural ingredients such as antifungal, antibacterial, and antiseptic (Utari and Desmawati, 2019). Most participants believe the Covid-19 pandemic is a test from God (59.9\%). Covid-19 occurs because humans have disrupted the balance of nature $(92.6 \%)$, humans have abused other creatures, such as animals and forests $(73.1 \%)$. The current Covid-19 pandemic is one of the impacts of disrupting the ecosystem. Loss of animal habitat in nature, or decreasing habitat conditions due to human activities in the conversion of forest land as livestock habitat for human life, can trigger zoonotic diseases transmitted through direct contact, 
food, water, and the environment (UNEP, 2020).

Most people hope that the spread of Covid19 in Indonesia will stop after entering the dry season because the Covid-19 virus dies in hot weather. Weather changes are highly correlated with changes in mortality from pneumonia (Bull, 1980). It refers to the theory that several factors influence virus transmission, including climatic conditions (such as temperature and humidity) (Dalziel et al., 2018). Kasilingam et al. (2021) found that weather is an integral factor in determining the incidence of Covid-19 in Jakarta. It was reported that the average temperature is significantly correlated with Covid-19. There is a correlation between weather and disease spread, and weather factors will suppress disease when the weather warms up (Guo, Zhang and Zeng, 2020). Sajadi's study revealed that temperature and humidity had a significant and consistent distribution of seasonal behavior of respiratory viruses (Sajadi et al., 2020). Absolute air temperature and humidity are indicated to significantly affect the transmission of Covid-19 (B. Chen et al., 2020). Variations in temperature and humidity can be important factors influencing Covid-19 mortality. There is a correlation between the spread of Covid-19 on temperature and climatic latitude (Poole, 2020). The pattern of climate change provides an overview of the occurrence of Covid-19 in Jakarta and its surroundings (Jabodetabek). It is in line with previous studies that reported a relationship between weather transmission and Syncytial Virus Respiration (RSV) (Vandini et al., 2013), SARS (Tan et al., 2005). Temperature is also an environmental driver of the Covid-19 outbreak in China (Shi et al., 2020).

On the other hand, the high mobility and population density in Greater Jakarta cause the increasingly massive spread of Covid19. Viruses can be transmitted by being influenced by population density (Dalziel et $a l ., 2018)$. The Greater Jakarta area is a very densely populated area. The majority of the population comes from provinces outside Jakarta. So that mobility in Jabodetabek is very high (Fitria and Setiawan, 2014). The people of Jakarta is 4 percent of the total population of Indonesia, around 9.6 million people. It has even increased to 4,4 percent (Surjadi and Surja, 2019). It has spread to Bogor, Depok, Tangerang, Bekasi (Zhu et al., 2020). In addition, weather factors, indoor air circulation are very important for the prevention of Covid-19. It is recommended to maintain good ventilation wherever it is (Rosenbaum, 2020). Occupational health and safety science 
state that air ventilation is the most important thing. Wearing a mask is the last and most effective protection in a closed, air-conditioned room, and it is advisable to use an exhaust fan (Amoatey et al., 2020; Qian and Zheng, 2018). The use of masks should be recommended for infected and healthy people to reduce the number of airborne droplets because they can transfer from human to human when coughing/sneezing in less than 5 seconds (Tang et al., 2020).

Table 4. Percentage of people awareness of infectious diseases $(n=297)$

\begin{tabular}{lcc}
\hline \multicolumn{1}{c}{ Questions } & \multicolumn{2}{c}{ Yes } \\
\cline { 2 - 3 } & n & \% \\
\hline If exposed, be prepared to undergo a health procedure & 293 & 98.7 \\
\hline Force oneself to be hospitalized if people are under surveillance & 293 & 98.7 \\
\hline $\begin{array}{l}\text { Sure that you can prevent yourself and your family from exposure to } \\
\text { Covid-19 }\end{array}$ & 44 & 14.8 \\
\hline Preventing and controlling Covid-19 is the duty of all Indonesian people & 293 & 98.7 \\
\hline Refrain from traveling & 293 & 98.7 \\
\hline Refrain from running away from the hospital if treated with Covid-19 & 292 & 98.3 \\
\hline Refrain from going to the hospital if it is not an emergency & 278 & 93.6 \\
\hline Position yourself not to be exposed to Covid-19 & 217 & 73.1 \\
\hline $\begin{array}{l}\text { Position yourself do not expose Covid-19 to others by always wearing a } \\
\text { mask, physical distancing, hand washing }\end{array}$ & 163 & 54.9 \\
\hline Preventing and handling Covid-19 is only the duty of the health workers & 28 & 9.4 \\
\hline $\begin{array}{l}\text { According to my point of view, I am at risk of being infected by Covid- } \\
\text { 19 }\end{array}$ & 197 & 66.3 \\
\hline $\begin{array}{l}\text { According to my point of view, my family is at risk of being infected } \\
\text { with Covid-19 }\end{array}$ & 143 & 48.2 \\
\hline
\end{tabular}

Table 4 shows that, on average, $71.11 \%$ of Jabodetabek residents have positive awareness of infectious diseases. Most of the participants forced themselves to be hospitalized when the status of patients under supervision (PDP). They are not sure that they can prevent themselves and their families from being exposed to Covid-19, and $45.1 \%$, because they cannot always use masks, wash their hands, and keep their distance. It shows the lack of public awareness and concern for the spread of Covid-19. On the other hand, most of the participants considered themselves and their families at risk of contracting COVID19. However, they are reluctant to wear masks and keep their distance when gathering. Further research is needed on the causes of people not complying with health protocols to prevent the spread of Covid19. 
Although many types of coronavirus exist in animals, Covid-19 has a rapid rate of person-to-person transmission and atypical symptoms at an early stage in certain patients (Chen et al., 2020). To anticipate this, it is necessary to know the average incubation period, which is 5-6 days, or the most prolonged incubation period, which is 14 days (Perlman, 2020). Fever and cough are the most common symptoms (T. Chen et al., 2020). Others can be in the form of acute respiratory distress and shortness of breath. In severe cases, Covid-19 can cause pneumonia, acute respiratory syndrome, kidney failure and even death. Clinical signs and symptoms reported in most cases were fever, with some cases having difficulty breathing, and X-rays showing extensive pneumonia infiltrates in both lungs (Holmes et al., 2020; Perlman, 2020), similar to SARS and MERS (Wang et al., 2020).

For some Covid-19 patients who have died, it is known that symptoms appear until they are hospitalized longer. It should be a concern so that public awareness to seek appropriate medical care and early referral to intensive care units for high-risk populations can be increased. The median time from symptom onset to death in patients who died was 16 days, and the median time from the first symptom to the onset of symptoms in recovered patients was 26 days, the most prolonged observed duration of virus spread in survivors was 37 days (Zhou et al., 2020). The average length of hospitalization before death is about five days. Symptoms such as fever, cough, fatigue, anorexia, myalgia, and diarrhea did not differ between patients who died and patients who recovered.

In contrast, dyspnea, chest tightness, and impaired consciousness were more common in those who died. In addition, vital sign data showed that most of the patients who died had tachycardia and/or tachypnea and a pulse oxygen saturation of 93\% or lower. These signs and symptoms indicate that most of the patients who died were in severe or critical condition while hospitalized. Therefore, there is a need for public awareness from an early age of the potential for infection in these conditions so that people immediately seek treatment or start treatment. Because most of the patients who died were already in severe or critical condition when hospitalized ( $\mathrm{T}$. Chen et al., 2020).

In addition, it is important to be aware of confounding factors such as age, gender, smoking status, comorbid factors (chronic hypertension and other cardiovascular diseases). These factors are more common in patients who died (48\% and 14\%) than 
patients who recovered $(24 \%$ and $4 \%)$. Shortness of breath, chest tightness, and impaired consciousness was more common in patients who died $(62 \%, 49 \%$, and $22 \%)$ than patients who recovered $(31 \%, 30 \%$ and $1 \%)$. In China, $113(14.4 \%)$ patients who died at that time were more likely to have comorbidities such as hypertension, diabetes, cardiovascular disease, or chronic lung disease (Jordan, Adab and Cheng, 2020). The risk will remain lower for younger people than for most older adults. The mean age of the patients who died was 68 years and significantly older than the recovered patients, 51 years. The highest mortality rate occurs in people aged 80 and over (T. Chen et al., 2020). The largest is based on a Chinese Center for Disease Control and Prevention report of the 44.000 people with laboratory-confirmed Covid19. Older age (40-60 years) with cardiovascular disease, diabetes, chronic respiratory disease, hypertension, and cancer were associated with an increased risk of death. There were no deaths reported among those under 40. Indeed, the male was more dominant in patients who died $(83 ; 73 \%)$ than patients who recovered (88; $55 \%)$. In China, out of 113 (14.4\%) patients who died at that time, most likely were male (Jordan, Adab and Cheng, 2020).

Table 5. Percentage of services or policies of the government based on local wisdom $(n=297)$

\begin{tabular}{lcc}
\hline \multicolumn{1}{c}{ Questions } & \multicolumn{2}{c}{ Yes } \\
\cline { 2 - 3 } & n & \% \\
\hline Is there a Covid-19 prevention protocol where you live & 242 & 81.5 \\
\hline $\begin{array}{l}\text { Is there a Covid-19 treatment protocol where you live for covid-19 } \\
\text { patients }\end{array}$ & 242 & 81.5 \\
\hline $\begin{array}{l}\text { Do you know the reporting flow if someone is found around you is } \\
\text { suspected of being Covid-19 }\end{array}$ & 228 & 76.8 \\
\hline $\begin{array}{l}\text { Government apparatus services related to Covid-19 where I live have } \\
\text { been satisfactory }\end{array}$ & 187 & 63 \\
\hline I appreciate the struggle of health workers in handling Covid-19 & 293 & 98.7 \\
\hline I appreciate the struggle of Covid-19 patients I achieving their recovery & 291 & 98 \\
\hline $\begin{array}{l}\text { I think the Indonesia government has been careless or has neglected to } \\
\text { deal with Covid-19 }\end{array}$ & 257 & 86.5 \\
\hline $\begin{array}{l}\text { I think Indonesian people are not serious/less obedient about preventing } \\
\text { the spread of Covid-19 }\end{array}$ & 219 & 73.7 \\
\hline $\begin{array}{l}\text { Surveillance in Indonesia is less sophisticated in preventing Covid-19 } \\
\text { I think the Indonesian government ignore local wisdom in handling }\end{array}$ & 230 & 77.4 \\
\hline \begin{tabular}{l} 
Covid-19 Pandemic \\
\hline
\end{tabular} & 226 & 76.1 \\
\hline
\end{tabular}


Table 5 shows that participants do not know the reporting flow if there are people around them who are suspected of being infected with Covid-19 (23.2\%). It is suspected that there is no protocol for the prevention and treatment of Covid-19 at their residence. Furthermore, participants assessed that the Indonesian government was not ready to handle Covid-19 (86.5\%). The lack of personal protective equipment for health workers has caused many doctors and nurses to die (Tempo, 2020). In addition, the Indonesian people are less serious and obedient in preventing the spread of Covid-19 (73.7\%), and the Indonesian government ignores local wisdom in dealing with the Covid-19 pandemic. Local wisdom is local wisdom based on cultural values or local traditions. Local wisdom results from a joint response with the surrounding environmental conditions to be used as potential energy in developing a civilized, clean, obedient, and healthy environment (Ridwan, 2007). Health, well-being, peace, tolerance, and success rest on one principle, namely moderation. Eliminate or reduce extremes. Based on the integration of knowledge, spirituality, values, and Indonesian local wisdom, it will be appropriate to overcome the current state of the Indonesian nation (Arifinsyah, Andy and Damanik, 2020).

Many regional policies have been launched by the Association of Traditional Law Teachers (APHA) and Community Based Nature Management to prevent the spread of Covid-19. Bukit Larangan, Kuta Village, Ciamis, has the Leuweng Gede customary forest (Windia et al., 2020); Sukadaya Village, Subang Regency, has wisdom values in maintaining the balance of nature (Taufiq, 2014); and trees in the Al-Zaytun campus forest are important for filtering the air, removing harmful pollutants, such as Carbon Monoxide (high levels of toxins), particulate matter (which causes asthma), and Basic Ozone (various respiratory effects including Covid-19) (Sidayu, 2020). Jabodetabek may be able to imitate this method to control the spread of Covid-19. 
Table 6. Total percentage for each response categories of public perspective Regarding the Covid-19 Pandemic

\begin{tabular}{lc}
\hline \multicolumn{1}{c}{ Categories } & $\begin{array}{c}\text { Total percentage } \\
\text { of positive } \\
\text { perspective (\%) }\end{array}$ \\
\hline $\begin{array}{l}\text { Characteristics of the disease and assumption of people about } \\
\text { Covid-19 Pandemic }\end{array}$ & 65.85 \\
\hline Values, belief, and culture in the environment & 66.13 \\
\hline People's awareness of infectious diseases & 71.11 \\
\hline Services or policies of the government with local wisdom & 81.32 \\
\hline
\end{tabular}

Table 6 shows the average value of the total categories, which is $71.10 \%$. Services or policies of the government with local wisdom become the best category in order to overcome Covid-19. This study shows a unique result of the Jabodetabek people's perception of the Covid-19 pandemic. Based on the results, it was found that people believe that Covid-19 is transmitted from wild animals consumed such as bats and snakes to a human being $(40.1 \%)$, and the presumption that Covid-19 can infect not only adults, but also children, and elderly people $(93.3 \%)$. Some participants believe that men are more susceptible to Covid-19 infection than women (19.9\%). There were still $30.6 \%$ dismiss that smokers are more susceptible to Covid-19 infection than non-smokers, there are $30.6 \%$ disbelieve that smokers are more susceptible to Covid-19 infection than nonsmokers, and $44.4 \%$ people assumed that avoided patients who had recovered from quarantine even though they had tested negative, and there is assume that Covid-19 emerged due to the sophistication of science and human technology (39.4\%).

When wild animals are used for food, pets, medicinal ingredients, or other purposes, it can certainly facilitate the transmission of zoonotic diseases (Broad, 2020). It is in line with Plotkin's research which found that most zoonotic transmissions are transmitted to humans, not due to animal diseases that bite humans, but human activities such as hunting, carrying, storing, keeping, selling, killing, and eating wild animals (Plotkin, 2020). In the Qur'an and the Hadith of the Prophet, there is knowledge about the importance of maintaining personal and environmental hygiene, including eating halal food and maintaining personal and environmental hygiene (Rifa'i et al., 2020). "So eat clean and good food from the sustenance that Allah has given you, and be grateful for Allah's blessings, if you only worship Him.(QS: An-Nahl (16): 114)”. 
The need to increase public knowledge about patients who have recovered from Covid-19 should not be avoided. Further research is needed to determine whether Covid-19 stems from the sophistication of science and technology.

\section{CONCLUSION}

In conclusion, the Jabodetabek community's perspective on the Covid-19 pandemic is good. Some of the participants in this study still had limited knowledge, tended to be misinformed about Covid-19, and made assumptions. Thus, negative attitudes and behaviors emerged, such as refusing to wear masks and not wanting physical distancing in public places. Therefore, it is recommended to increase health promotion activities (rebuild trust, the precautionary principle, social distancing or physical distancing, washing hands and wearing masks), providing psychosocial support (optimism, quick response, and detection, communication with each other). The management strategy in the community is through traditional therapy with local wisdom approaches such as encouraging people to consume traditional drinks such as herbal medicine (ginger-turmeric) or infused water. Indepth, it is also important to be aware of obeying religious orders' mental and spiritual aspects.

\section{ACKNOWLEDGEMENT}

The authors would like to thank Universitas Pembangunan Nasional Veteran Jakarta for the research funding assistance provided and to all participants involved in this research.

\section{REFERENCES}

Amoatey, P. et al. (2020) 'Impact of Building Ventilation Systems and Habitual Indoor Incense Burning on SARS-CoV-2 Virus Transmissions in Middle Eastern Countries', Science of The Total Environment. Elsevier, 733(1), p. 139356. doi: https://doi.org/10.1016/j.scitotenv.202 0.139356 .

Arifinsyah, A., Andy, S. and Damanik, A. (2020) 'The Urgency of Religious Moderation in Preventing Radicalism in Indonesia', ESENSIA: Jurnal IlmuIlmu Ushuluddin, 21(1), pp. 91-108. doi:

https://doi.org/10.14421/esensia.v21i1 .2199 .

Broad, S. (2020) Wildlife Trade, COVID19, and Zoonotic Disease Risks, TRAFFIC. UK.

Bull, G. M. (1980) 'The weather and deaths from pneumonia', The Lancet, 315(8183), pp. 1405-1408. doi: https://doi.org/10.1016/S01406736(80)92666-5.

Charon, J. M. (2010) Ten Questions: A Sociological Perspective. 7th edition. USA: Cengage Learning.

Chen, B. et al. (2020) 'Roles of Meteorological Conditions in COVID19 Transmission on a Worldwide Scale', MedRxiv, Pre-print. doi: https://doi.org/10.1101/2020.03.16.20 
037168 .

Chen, T. et al. (2020) 'Clinical Characteristics of 113 Deceased Patients with Coronavirus Disease 2019: Retrospective Study', BMJ, 368(m1091), pp. 1-12. doi: https://doi.org/10.1136/bmj.m1091.

Cucinotta, D. and Vanelli, M. (2020) 'WHO Declares COVID-19 a Pandemic', Acta Biomedica, 91(1), pp. 157-160. doi: https://doi.org/10.23750/abm.v91i1.9 397.

Dalziel, B. D. et al. (2018) 'Urbanization and Humidity Shape The Intensity of Influenza Epidemics in US Cities', Science, 362(6410), pp. 75-79. doi: https://doi.org/10.1126/science.aat603 0 .

Desmawati et al. (2021) 'Knowledge, Attitude, and Behaviours Towards Covid-19 Transmission Among Jakarta-Bogor-Depok-TangerangBekasi Residents', Jurnal Keperawatan Soedirman, 16(2), pp. 76-80. doi: https://doi.org/10.20884/1.jks.2021.16 .2.1612.

Desmawati, Kongsuwan, W. and Chatchawet, W. (2019) 'Effect of Nursing Intervention Integrating an Islamic Praying Program on Labor Pain and Pain Behaviors in Primiparous Muslim Women', Iranian Journal of Nursing and Midwifery Research, 24(3), pp. 220-226. doi: https://doi.org/10.4103/ijnmr.IJNMR_ 36_18.

Desmawati, Kongsuwan, W. and Chatchawet, W. (2020) 'The Effects of Childbirth Preparation Nursing Intervention Integrating Islamic Praying Program on Duration of Labor and Neonatal Outcomes in
Primiparous Muslim Women', Walailak Journal of Science and Technology (WJST), 17(10), pp. 1048$1059 . \quad$ doi: https://doi.org/10.48048/wjst.2020.54 56.

Fitria, N. and Setiawan, R. (2014) 'Identifikasi Karakteristik Lingkungan Permukiman Kumuh di Kelurahan Kapuk, Jakarta Barat', Jurnal Teknik ITS, 3(2), pp. C240-C244. doi: https://doi.org/10.12962/j23373539.v 3i2.7290.

Guo, X.-J., Zhang, H. and Zeng, Y.-P. (2020) 'Transmissibility of COVID-19 and Its Association with Temperature and Humidity', Research Square, Preprints, pp. 1-10. doi: https://doi.org/10.21203/rs.3.rs17715/v1.

Holmes, E. A. et al. (2020) 'Multidisciplinary Research Priorities for The COVID-19 Pandemic: A Call for Action for Mental Health Science', The Lancet Psychiatry, 7(6), pp. 547560. doi: https://doi.org/10.1016/S22150366(20)30168-1.

Jordan, R. E., Adab, P. and Cheng, K. (2020) 'Covid-19: Risk Factors for Severe Disease and Death', $B M J$, 368(m1198), pp. 1-2. doi: https://doi.org/10.1136/bmj.m1198.

Kasilingam, D. et al. (2021) 'Exploring The Growth of COVID-19 Cases Using Exponential Modelling Across 42 Countries and Predicting Signs of Early Containment Using Machine Learning, Transboundary and Emerging Diseases, 68(3), pp. 10011018. doi: https://doi.org/10.1111/tbed.13764. 
Kementerian Kesehatan RI (2020) A Dashboard of COVID-19 Cases in Indonesia. Jakarta. Available at: https://infeksiemerging.kemkes.go.id/ dashboard/covid-19.

Khaedir, Y. (2020) 'Pendekatan Aspek Virologi Dan Epidemiologi Klinik', Jurnal Maarif Institute, 5(1), pp. 4055.

Perlman, S. (2020) 'Another Decade, Another Coronavirus', $N$ Engl J Med, 382(8), pp. 760-762. doi: https://doi.org/10.1056/NEJMe20011 26.

Plotkin, M. J. (2020) Coronavirus and Conservation: Preventing the Next Pandemic. Los Angeles: Oxford University Press.

Poole, L. (2020) 'Seasonal Influences On The Spread Of SARS-CoV-2 (COVID19), Causality, and Forecastabililty (3-15-2020)', SSRN, pp. 1-12. doi: https://dx.doi.org/10.2139/ssrn.35547 46.

Qian, H. and Zheng, X. (2018) 'Ventilation Control for Airborne Transmission of Human Exhaled Bio-aerosols in Buildings', Journal of Thoracic Disease, 10(Suppl 19), pp. S2295S2304.

doi: http://dx.doi.org/10.21037/jtd.2018.01 .242304 .

Ridwan, N. A. (2007) 'Kearifan Lokal: Fungsi dan Wujudnya', Jurnal Studi Islam dan Budaya, 5, pp. 1-8.

Rifa'i, I. et al. (2020) Dampak dan pencegahan wabah Covid-19: Perspektif Sains dan Islam, Thesis. UIN Sunan Gunung Djati.

Rosenbaum, L. (2020) 'Facing Covid-19 in Italy - Ethics, Logistics, and Therapeutics on the Epidemic's Front
Line', $N$ Engl J Med, 382(20), pp.

1873-1875.

doi: 10.1056/NEJMp2005492.

Sajadi, M. M. et al. (2020) 'Temperature, Humidity, and Latitude Analysis to Estimate Potential Spread and Seasonality of Coronavirus Disease 2019 (COVID-19)', JAMA Netw Open, 3(6), pp. e2011834-e2011834. doi:

https://doi.org/10.1001/jamanetworko pen.2020.11834.

Shi, P. et al. (2020) 'The Impact of Temperature and Absolute Humidity on The Coronavirus Disease 2019 (COVID-19) Outbreak-Evidence from China', MedRxiv, Preprint, pp. 1-27. doi:

https://doi.org/10.1101/2020.03.22.20 038919.

Sidayu, A. (2020) 'Manfaat Hutan Kampus Al Zaytun di Masa Sulit akibat Virus Corona', Kompasiana, 16 April.

Surjadi, C. and Surja, S. S. (2019) Kesehatan Perkotaan di Indonesia. Jakarta: Penerbit Universitas Atma Jaya.

Tan, J. et al. (2005) 'An Initial Investigation of The Association Between The SARS Outbreak and Weather: with The View of The Environmental Temperature and Its Variation', Journal of Epidemiology \& Community Health, 59(3), pp. 186192. doi: http://dx.doi.org/10.1136/jech.2004.0 20180.

Tang, B. et al. (2020) 'Coronavirus Disease 2019 (COVID-19) Pneumonia in a Hemodialysis Patient', Kidney Medicine, 2(3), pp. 354-358. doi: https://doi.org/10.1016/j.xkme.2020.0 3.001 . 
Desmawati, F. Bachtiar, Public Perspectives Regarding Covid-19 Pandemic: A Survey of 48 Adults in Jakarta Bogor Depok Tangerang Bekasi Area

Taufiq, A. (2014) 'Upaya Pemeliharaan Lingkungan oleh Masyarakat di Kampung Sukadaya Kabupaten Subang', Jurnal Geografi Gea, 14(2), pp. 124-132. doi: https://doi.org/10.17509/gea.v14i2.34 02.g2394.

Tempo (2020) 'Untung Buntung Pandemi', September, pp. 7-13.

UNEP (2020) Preventing The Next Pandemic: Zoonotic Disease and How to break The Chain of Transmission. Kenya: UNEP Publicaton.

Utari, P. E. and Desmawati (2019) 'Effect Turmeric Acid Consumption On The Menstrual Pain In Young Women In Al-Hamid Islamic Boarding School Jakarta And Nur Medina Islamic Boarding School Tangerang', in International Conference On Health Development. Jakarta: FIKES, UPNVJ.

Vandini, S. et al. (2013) 'Respiratory Syncytial Virus Infection In Infants And Correlation With Meteorological Factors And Air Pollutants', Italian Journal of Pediatrics volume, 39(1), pp. 1-6. doi: https://doi.org/10.1186/1824-7288-
$39-1$.

Wang, Yixuan et al. (2020) 'Unique Epidemiological And Clinical Features Of The Emerging 2019 Novel Coronavirus Pneumonia (Covid-19) Implicate Special Control Measures', $J$ Med Virol., 92(6), pp. 568-576. doi: https://doi.org/10.1002/jmv.25748.

Windia, W. P. et al. (2020) 'Bunga Rampai APHA Indonesia: Melihat Covid-19 dari Perspektif Hukum Adat', Journal of Indonesian Adat Law, p. 373. doi: https://doi.org/10.46816/jial.v1i1.

Zhou, F. et al. (2020) 'Clinical Course And Risk Factors For Mortality Of Adult Inpatients With Covid-19 In Wuhan, China: A Retrospective Cohort Study', The Lancet, 395(10229), pp. 10541062. doi: https://doi.org/10.1016/S01406736(20)30566-3.

Zhu, N. et al. (2020) 'A novel coronavirus from patients with pneumonia in China, 2019', N Engl J Med, 382(8), pp. 727-733. doi: https://doi.org/10.1056/NEJMoa2001 017. 